\title{
Organizational Change and Its Effect on Employee Efficiency in Andhra Pradesh Southern Power Distribution Company Limited
}

\author{
V Tulasi Das*
}

\section{Abstract}

Organizations today are operating in a fast changing environment where business practices are dynamic and economies are vulnerable to market fluctuations. A potential threat from external environment requires organizations to be much more dynamic in nature. In the process of survival, sustainability, and growth, organizations are initiating change by re-orienting their systems, structures, and processes, particularly organizational processes. Further, the need for change in organizations is not only triggered by the environment they operate in (which is fiercely competitive), but also from within. Introduction of new technology, changing social and lifestyle patterns, career aspirations of organizational members, and frequent changes in consumer priorities have contributed to the evaluation of this complex web of change. Organizations, globally, are constantly trying to device a wide variety of strategies to cope with these changes. There is great resistance to change because of the fear of the unknown. Employees in the organization therefore must be educate, trained, made party to change, and the benefit of change must be divided between the employees and the organization to enhance the employee efficiency. It is handling of employee emotions and making them psychologically

*Dept of Human Resource Management, Acharya Nagarjuna University, Guntur - 522510, Andhra Pradesh. Email: chinmaitulasi@gmail.com 
ready to implement change that will ultimately work. The fear must be removed from the minds of the employees. It must be emphasized that change brings with new challenges, new experiences, sprit and associated reward and, therefore it should be welcomed and implemented with positive attitude and full support.

Keywords: Organizational change, employee efficiency, improved performance, APSPDCC (Andhra Pradesh Southern Power Distinction Company Limited).

\section{Introduction}

Organizational change is the adoption of a new idea or behaviour by an organization. It is a way of modifying an existing organization any alteration of people, structure and technology. The purpose of undertaking such modification is to increase organizational effectiveness, that is, the extent to which an organization achieves its objectives. Organizational change is largely structural in nature as it brings about modifications in organizational structure, methods and processes. Most managers agreed that if an organization has to be successful, it must change continually in response to significant developments such as customer needs, technological breakthroughs, economic shocks and government regulations. It is not sufficient today to simply react to change; managers need to anticipate change and ideally be the creator of change. Managing change involves an array of activities, such as creation of organizational identities, knowledge development and its institutionalization, management of diversity, constant up graduation of technology, alignment of strategic goals with economic environment, asset management, creation of appropriate culture, restructuring of roles, coping with market competition, and management of internal as well as external crises.

Now-a-days the change in any organization has become inevitable to meet the competition and to improve the efficiency. But in general, the human nature is to resist the change first and if the need for change or benefits of change are explained in a lucid way then it will make the employees to know better about the necessity of the change and in turn will make them a part of the organizational growth in most of the organizations, let it be 
infrastructure industries, software or banking sector they receive suggestion from the management consultants and the experts in adopting the organizational change. With the increasing trend of the automation for the production industries development of software for information technology industries and improvement of services for the Banking Sector and the Railways, the need for change is indispensable.

Electricity is one of the most vital infrastructure inputs for economic development of a country. Worldwide the countries are now competing for supremacy not in defence capabilities, but in areas like energy. In today's infrastructure requirement in the world, electricity is the most essential component. Without ready availability of cheaper energy, the greater strides taken by the society, industry, transport and agriculture could have been unimaginable. Consumption of electricity is considered one of the yardsticks to measure the development of the nation. Consumption of electrical power in India is $606 \mathrm{KWH} /$ Year per capita as against the global average level of $9090 \mathrm{KwH} /$ year per capita. The growth rate of demand for power in India is higher than that of the gross domestic product (GDP). With a target GDP growth rate, India's energy requirement is expected to grow at 6.4-8 per cent. The progress in the Indian power sector, with current electricity shortages of over 16 per cent of peak and 10 per cent of energy will be one of the key determinants of the future growth and one of the primary growth engines of the economy. This mean that there will be fivefold increase in energy needs in the next 25 years. This paper focuses on the Organizational Change and its Effect on Employees in APSPDCL in Andhra Pradesh.

\section{Objective of the Study}

- To study the growth and performance of A.P.TRANSCO,

- To examine the effect of organizational change on the employee efficiency,

- To elicit the opinion of employees of APSPDCL on organizational change and its impact on employee efficiency, 
- To put forth certain conclusions based on the findings that have been arrived.

\section{Methodology of the Study}

People, service, and results are the foundation of a successful organization. Achieving success or excellence with focus on quality and customer satisfaction are the end results of organizational performance and members of the organization are the actual contributors in this process. Hence, organizational excellence is possible only when effective people make use of effective processes, and they are effectively managed through enhanced efficiencies.

To fulfil the aforesaid objectives the following methodology was used. The data was collected through primary and secondary sources. Primary data was the data which was collected directly by survey through well-designed questionnaires from the sample of 75 employees of different categories of APSPDCL. Secondary data was collected from the books, journals, case studies, the administrative reports of the APSPDCL etc.

\section{Sampling}

- Total sampling of the study: 75

- Area of sampling: APSPDCL, Andhra Pradesh

- Type of sampling: Random selection

- Type of questionnaire: Anonymous

\section{Limitation of the Study}

The study on organizational change its effects on efficiency of employee are not free from some limitations. For example, the opinion of the employee may alter in future according to the situation, and the study also has some limitation such as cost, time, and effort. 


\section{Review of Literature}

The term organizational change implies the creation of imbalance in the existent pattern or situation. Adjustment among people, technology and structural set upsare established when an organization operates for a long time. People adjust with their jobs, working conditions, colleague superiors etc. Since change is the key for development of any organization in a competitive market environment, it has attracted the attention of researchers, economists, behavioural scientists, policy makers and organizations immensely. Several research studies have been conducted in the concerned areas. Here an attempt is made to review some of the important research studies.

Herscovitch and Meyer (2002) gave the accelerated rate and complexity of changes in the workplace. It is surprising that there is a large and growing literature on the causes consequences and strategies of organizational change. What is surprising however is that the paucity of research on employee reactions to change introduced a three component model of commitment to organizational change and demonstrated that employee commitment to a change is a better predictor of behavioural support for a change than is organizational commitment is the three components are effective, normative and continuance.

Paton and McCalman,(2002) contended that organizational success is generated by motivated people. Furthermore, the greater the job, greater is the employee commitment to the organization and organizational change. Chakravathy improvements in organizational performance involve employee perceptions about financial and non-financial effects of the organizational performance. Nonfinancial performance includes variables such as customer satisfaction, customer loyalty and market share. Financial performance includes measure for return on sales, return on investment and return on assets.

Jane Andrews, Helen Cameron, Margaret Harris (2008) finds that the complexities of managing change in practice reflect distinctive organizational environments and cultures. The skill and knowledge which managers found most useful were those that enabled them to "make sense" of the organizational change they subsequently 
experienced. The main impact of their earlier studies was to prompt informative discursive and reflective approaches to change management. Doyle, Claydon, Buchan (2002)suggest that the public sector managers have much less satisfactory experiences of change than their private sector counterparts. They attribute this largely to the nature of public policy which they describe as "bases upon ministerial edict (combined with threat), highly controversial in substance, tight and non-negotiable timescale, no planning window, no consideration of the logistical and political implementation issues.

Keith Daivs and Udai Pareek (1988) "It implies the creation of imbalances in the existent pattern of situation. Adjustment among people, Technology \& structural set up is established when an organization has operated for a long time". Warren G Bennis and A Wiley (1969) considered change to be both reactive and proactive. A proactive change has a necessity to be planned to attempt to prepare for anticipated challenges. A reactive change may be an automatic response or a planned response to change taking place in the environment. Stephen P Robbins (2000)introduced the HRD technologies that help the employees to acquire new skills and knowledge necessary to carry out the changed duties due to the up gradation of technology.

Cao and Mchugh(2005) said that the ability of organizations to manage and survive change is becoming increasingly important in an environment where competition and idolization of market are ever intensifying. Brown Elisenhardt, Morel and Ramanujam(1998), are of opinion that organizations are dynamic system of adaptation and evolution that contain multiple parts which interact with one another and the environment. The ability of the organization to change rapidly in response to intra and inter relationship is at the heat of an adaptive organization. Mccalman(2000) Contended that organizational success is generated by motivated people. Furthermore the greater the job motivation, the greater is the likelihood of employee commitment to the organization and to organizational change.

As per Graetz and Senior (2000) Due to the importance of organization change, its management requires a huge amount of managerial skill 'against a backdrop of increasing globalization, 
deregulation, the rapid phase of technological innovation, and a growing knowledge workforce. Few would dispute the fact that the primary task for management today is the leadership of organizational change. Luecke (2003) says that the successful management of change is accepted as a necessity in order to survive and succeed in today's highly competitive and continuously evolving environment. Riely and Clarkson (2001) in their early approaches were of the opinion that organizations could not be effective or improve performances if they were constantly changing. It was argued that people need routines to be effective and to be able to improve performance. Burness (2004) refers to incremental change as when individual parts of an org deal increasingly and separately with one problem and one objective at a time. Advocates of this view argue that change is best implemented through successive, limited and negotiated shifts. Eldrod II and Tippet (2002) proposed that before change and new behaviour can be adopted successfully the previous behaviour has to be discarded. The successful behaviour will be change to organization culture.

Bamford and Forrester (2003) put forth planned approach to change that has been long established and held to be highly effective. Firstly it is suggested that the approaches emphasis is on small scale and incremental changes. Secondly, the planned approach is based on the assumptions that organization operate under constant conditions. Thirdly, the ten approach of planned change ignores situations where move directive approaches are required. As per Burness (2004) the emergent approach to change emphasizes that change should not be perceived as a series of linear events within a given period of time, but as a continuous open-ended process of adoption to changing circumstances and conditions. Clarkson (2001) said that organization behaviour of change requires individuals and organizations to make new adjustments and also adapt to the new changing internal and external environments to change the organization. Luecke (2003) mentioned that emerging change mobilize energy and commitment through joint identification of business problems and their solutions, identify the leadership focus on results, not on activities and starts change at the periphery, then lets it to spread to other 
units without pushing it from the top. Moran and Brightman (2001) define management as the process of continually renewing an organization direction, its structure and capabilities to serve the ever-changing needs of external and internal customers. Change is an ever-present feature of organization life, both at an operational and strategic level.

\section{APSPDCL: An Overview}

The Andhra Pradesh State Electricity Board was constituted with effect from 01-04-1959, in accordance with the provisions of the Electricity Supply Act of 1948. The Board was responsible for promoting the co-ordinate development of generation, transmission and distribution of electricity in Andhra Pradesh. The Board was also responsible for formulation and implementation of internal policies. The distribution networks, the planning and the execution of rural Electrification in the State consisting of an operation circle was divided in to seven Zones, each headed by a Chief Engineer (operation) of the system. The Director (personnel) of the rank of the Chief engineer is in charge of administration. The Accountant wing of the Board was headed by the three FA \& CCAs. Other common services were under the control of the Joint Secretary (General Service). AP Power Sector Reforms envisage creation of Distribution Companies, as Government Undertakings for the first few years and privatizations later on. The Andhra Pradesh Gazette No.37 published by the Government of Andhra Pradesh on Friday the 31st of March 2000, declared formally the formation of Distribution Companies. In this process, Andhra Pradesh Southern Electricity Distribution Company was formed for the following six districts of Andhra Pradesh. The Corporate Office and Headquarters of APSPDCL are at Tirupati City. Quality power at economic rates acts a catalyst in transforming the state by fostering growth in agricultural, industrial and commercial areas while meeting the increasing domestic demand. On Feb 1, 1999, Government of Andhra Pradesh initiated the first phase of reforms and restructuring in AP's power sector by unbundling APSEB into APGENCO and APTRANSCO to cater to Generation and Transmission and Distribution of power respectively. APTRANSCO was further reorganized into four distribution 
companies to cater to the needs to the different districts of AP.APSPDCL was formed in April 1, 2000 to serve Krishna, Guntur, Prakasam, Nellore, Chittoor and Kadapa districts with a vision to 'become an efficient utility supplying reliable and quality power, promoting economic development and being self-reliant commercially'. As on 31st March 2010, APSPDCL had a robust distribution network to cater to customers spread across 81331 sq. $\mathrm{Km}$ representing 326 Mandals, 6177 villages and 86 assembly constituencies.

\section{APSPDCL PERFORMANCE HIGHLIGHTS}

\begin{tabular}{|l|r|r|r|r|r|}
\hline \multicolumn{1}{|c|}{ Year ended 31 $1^{\text {st }}$ March } & \multicolumn{1}{c|}{2010} & \multicolumn{1}{c|}{2009} & \multicolumn{1}{c|}{2008} & \multicolumn{1}{c|}{2007} & \multicolumn{1}{c|}{2006} \\
\hline Units Sold (Million Units) & 13697.28 & 11938.50 & 10798.24 & 10360.95 & 9118.54 \\
\hline No. of 33/11 KV Sub stations & 1045 & 955 & 843 & 767 & 700 \\
\hline Length of 33 KV line in KM & 11506.29 & 10891.65 & 10272.61 & 9960.10 & 9601.31 \\
\hline Length of 11 KV line in KM & 91863.79 & 84734.16 & 75012.36 & 70173.41 & 64626.11 \\
\hline Length of LT line in KM & 141082.90 & 139692.10 & 132688.92 & 130361.92 & 129381.08 \\
\hline $\begin{array}{l}\text { Number of Distribution } \\
\text { Transformers }\end{array}$ & 249957 & 226238 & 184972 & 158160 & 139020 \\
\hline $\begin{array}{l}\text { Number of Power } \\
\text { Transformers }\end{array}$ & 1357 & 1261 & 1147 & 1071 & 1003 \\
\hline No of Consumers & $63,97.861$ & 6021853 & 5656339 & 5234494 & 4849471 \\
\hline Distribution Losses (\%) & 12.98 & 13.52 & 14.73 & 15.97 & 16.98 \\
\hline $\begin{array}{l}\text { Distribution Transformer } \\
\text { failures (\%) }\end{array}$ & 7.12 & 6.80 & 7.67 & 8.96 & 9.10 \\
\hline $\begin{array}{l}\text { Average Realisation per unit } \\
\text { (Rs.) }\end{array}$ & 2.32 & 2.27 & 2.29 & 2.09 & 2.11 \\
\hline $\begin{array}{l}\text { Financial Data (Rs. in } \\
\text { Crores) }\end{array}$ & 5765.2815 & 5291.15 & 3837.47 & 3251.14 & 2926.52 \\
\hline Total income & 3.9802 & 10.98 & 54.16 & 53.18 & 37.08 \\
\hline Total Expenditure & 358.71 & 358.71 & 358.71 & 358.71 & 358.71 \\
\hline $\begin{array}{l}\text { Surplus / (Deficit) } \\
\text { Paid up Equity Capital } \\
\text { (Rs. In Crores) }\end{array}$ & 5302.13 & 3891.63 & 3304.32 & 2963.60 \\
\hline
\end{tabular}


Andhra Pradesh is mainly an agricultural potential State which depends mainly on the electricity pumps. There were 15 lakh pumps sets in the State being used only for ruby crops and commercial crops. So, the Government of A. P. was providing power to the State Agricultural Sector to encourage farmers for sowing crops. Then the state power demand was 7,500 MW and only one or two private power plants were 75,000 and the salaries of the total employees was around 100 Crore/annum. Then the financial performance of the Electricity Boards was measured by the rate of return basis as it should be minimum 3\% for the viability of the organization. But under the influence of the Union Government's liberalization polices, the state electricity boards were restructured into two corporations under the 1956 Companies Act named as AP Transco \& AP Genco from 01 Feburary,1999. The main function of AP Genco was to generate power and sell it to AP Transco. The main function of AP Transco was to transmit power to various districts and distribute it to several categories of consumers.

Later in 2000, A. P.Transco was divided in to 5 companies, as AP Transcoas the main holding company and four distribution companies as its subsidiaries. The main function of A.P. Tranco is to transmit power from various sources and to sell it to the 4 distribution companies viz APSPDCL (6 district of Krishna, Guntur, Prakasam, Nellore,Chittor, Cuddapah )AP EPPDCL (W.G.Dist, E.GDist, Visakhapatnam, Vizianagaram, Srikakulam,) and APNPDCL (Warangal,Khammam, Karimnagar, Nizamabad, Adilabad) APCPDCL (Hydeabad, Secundarbad, RR Dist, Medak, Nalgonda, Mahaboob Nagar, Kurnool, Ananthapuram).

The main purpose of the power reforms by the Government is to servethe consumer in a better way and to improve the responsibility and accountability of the employees in men and material management and to see financial viability of the companies, when split into smaller companies. Here, the focus is to present with this organizational change, how the companies perform prior and after the reforms and its effects on employees in Prakasam District, as presented case study with questionnaires. 


\section{Organizational Change that Occurred in APSPDCL: Initiatives to Improve Performance}

The companies have taken up a series of efficiency improvement initiatives to improve the performance of the companies in the technical, commercial and financial area and have focused on customer service initiatives for improved customer satisfaction. Some of the initiatives are:

\section{i) Technical Initiatives}

1038 express industrial feeders have been separated and ensured uninterrupted quality supply to industries. These feeders are continuously monitored to reduce interruptions, if any, and to ensure good voltage levels. An important and successful intervention has been regulation of agricultural supply through single- phasing of lighting supply to rural domestic consumers, while controlling three-phase supply to agriculture. This segregation of lighting supply in 5489 feeders has enabled the companies to effectively regulate three - phase supply to agriculture, and has improved the quality to power supply in the rural areas. SCADA is implemented and operational in 93 Nos of 33/11 KV sub-stations and 13 Nos of EHV sub-stations in Hyderabad Urban Development Authority (HUDA) area. 118 nos industrial feeders, 642 No s $11 \mathrm{KV}$ feeder and 33 NO.s $33 \mathrm{KV}$ feeders dispatch centres and the state load dispatch centre. High voltage distribution system (HVDS) is introduced for reliable and quality supply for domestic and agriculture consumers. So far 172668 numbers of agricultural pump sets are covered under HVDS.

\section{ii) Commercial and Financial Initiative}

Billing payments have been made convenient through 250 e-seva centres and 1400 computerized Rural Service Delivery (RSDP) spot billing is being implemented throughout the state for LT category consumers monthly spot billings being done in all towns and municipalities. During the year 2007-08, 165510 cases were booked on theft and malpractice with penal assessment of Rs. 31.89 crore, 2710 people have been arrested for power theft and Rs.12.93 Crs 
has been collected as compounding fees from 130,670 cases. Comprehensive energy audit was taken up on 114 selected towns as they draw considerable amount of power, and they also register the highest revenue in absolute terms as well as specific revenue in the L.T. Sector. Losses in 105 towns were brought down below 10\% loss in Hyderabad is to the tune about $28.65 \%$.Boundary metering with 0.5 class accuracy, meters at 562 points and 0.2 Transco of the four distribution companies. So far 83 points of interface between AP Genco have been metered with 0.2 class accuracy meters. No new connection is being released without meter. 30,000 energy meters have been installed on LV side of transformers exclusively feeding agricultural services installed to assess the pattern of agricultural consumption in the state as per the methodology approved by APERC. Certain key activities as explained below have been outsourced to improve performance and productivity.

- Collection process out sourced through e-seva and rural kiosks called Rural Services very Points (RSDP) and this has been found convenient to customers. Almost $40 \%$ of low tension (LT) service collections are outsourced.

- Class IV services such as watch and ward, housekeeping and transportation are outsourced to a large extent.

- IT data base management is $100 \%$ outsourced.

The contracts with these out sourced agencies have penalty clauses for poor performance.

Metering Plan for Increasing Revenues: The utilities have taken a strategic decision in terms of changing of meters. Electronic meters have been deployed for all the high value consumers and high quality electro - mechanical meters for the other consumers to replace old/sluggish meters.

\begin{tabular}{|l|l|l|}
\hline Particulars in (Lakhs) & $2008-2009$ & $2009-2010$ \\
\hline \hline Number of New meters installed & 18.9 & 24.6 \\
\hline
\end{tabular}

Application of IT: Following IT initiatives are used place to improve accountability, transparency and service delivery. Consumer Analysis Tool (CAT) for targeting regulations in 12 
metering, billing and collection. Transformer information Management System (TIMS) to assist in analyzing report of transformer failure and facilitate preventive maintenance. Monitoring and Tracking System (MATS) has been implemented to improve inspection efficiency and reduce commercial losses. Energy Management System (EMS) for merit order dispatch which helps in power purchase cost reduction. Monthly Review System (PMRS) performance Monitoring and reporting system has been introduced for MIS. Enterprise Resource Planning (ERP) is introduced in AP Transco and DISCOMS. Remoter meter reading (RNR) has been taken up to improve transparency and avoid / detect any tampering.

Customer Service: Customer service is primary for utilities. Citizen charter is in place and implementation monitored through call centres.336 customer service centres have been established in all towns and at sub-division level in rural areas. Out of this 221 CSCs are exclusively for Rural areas. These centres have been outsourced in order to ensure that every complaint / Request is registered. Appropriate IT systems are in place on-line. The senior Management team reviews the status of compliance with respect to standards of performance, though the network regularly. Meetings are held in District headquarters every month with industrial consumer. Substation-wise meetings are held during khariff and rabi seasons to address the concerns of farmers. Distribution transformer (DTR) replacement centres for rural areas have been increased from 85 to 260 for speedy replacement. Since the maximum number of complaints relate to billing, and to take the redressed machinery closer to rural customers, 'VidyutAdalats' are conducted once in a week on Monday in each of the 1126 Mandals in the State for on-the Spot rectification of billing and other related complaints.

Collection system in rural areas has been streamlined. In addition to departmental collection centres, the utilities, through Rajiv Internet, have set up 850 RSDP e-kiosks, and 600 more will be established shortly with effective security mechanisms. Rajiv Internet it is proposed to cover 8000 major villages through a franchisee system, of which have been already. The Principal Rajiv 
Partner (PRPs) provides the required securities. This is proposed to be rolled out to cover all the villages.

Some of the results of the customer service initiatives include.

- Reduction in billing complaints and quick redressed. Billing complaints have reduced significantly over the years.

- New services are being released within 24 hours in urban areas.

- Failed distribution transformer (DTRs) is being replaced within 6 hours in urban areas (against SOP norm of 24 Hours) and in rural areas DTS's are being replaced within 48 hours as per SOP norm.

- Compliance in the standards of performance is over $98 \%$.

- Collections through e-seva in urban areas and through ekiosks in rural areas have significantly helped the consumers.

\section{iii) Human Resources Management Skill Building Initiatives}

The employee's consumer ratio (actual employees per 1000 consumer) is at 2.61 and the total revenue employee ratio at Rs.24.36 lakh per employee is one of the best in the country. With this organizational change, a lot of development in the organization with respect to financial status and with respect to employees been occurred and this reveals that change is inevitable for any organization to survive. But the main thing that is to be taken in to consideration here is that generally employees are reluctant for change. The management has to educate and counsel the employees on the necessity of change for improvise the organization as well as self and change should be in accordance with the Government policies. Of course, it is needless to say that there are same merits and de-merits of the change initially. We have to accept and adopt the merits in a planned manner and in the case of demerits, we have to scrutinize how de-merits can be converted into merits as soon as possible. As seen in the earlier organizational structure, of post re-forms organizational structure, there is a crystal clear change in the employees and employers pattern a in the entire electricity board which of75,000 employees. 14 
here was only one director (personnel) who took care of the entire administration but for the post reforms structure of every company there is a post of Chief General Manager (Admn) to look after the administration of the respective company employees.

There was only one member secretary who was in the IAS cadre appointed by the Government of Andhra Pradesh but now the IAS officers in AP Transco are: Chairman of managing Director, Joint Managing Director (HRD) and RAC and 4 to 5 directors in each company where as in DISCOMS only 4 IAS officers are posted for each company as Chairman and Managing Director and 4 to 5 director are there in each company.

So, with the same employee strengths the highest level organization change is shown below

\begin{tabular}{|l|c|c|c|}
\hline & IAS & $\begin{array}{c}\text { Director / } \\
\text { Members }\end{array}$ & CGMS \\
\hline \hline Pre - reforms & 1 & 6 & 1 \\
\hline \hline Post reforms & 6 & 28 & 5 \\
\hline
\end{tabular}

It is clearly observed that the number of higher level officers strength has been increased 5 to 6 times at the bottom level cadre (field level) has not been resolved that much. The main reason is that the outsourcing or manning of field level functions i.e., with the network raising rapidly for the last 5 years the no of $400 \mathrm{KV}$, $220 \mathrm{KV}, 132 \mathrm{KV}$ sub-station are increasing yearly, the staff in the $132 \mathrm{KV}$ sub-station is supplied by the manning contractor and just we have to get the required work gets done with the staff and payment is made through the contractor for which AP Transco will not bear any responsibility with the establishment of the Managing staff. As per the labour rules and regulation we pay the consolidated amount to the contractor for arranging the staff. But as far as the department responsibility is concerned, we have to supervise / monitor the load management / power management issues over all within a division by the concerned assistant divisional engineers and the regular maintenance of the Sub-station is done by the concerned assistant engineer. 
With this arrangement the employees of the organization have fallen to the nearest minimum and the organization reduced the administrative expenditure as far as possible. But as far as responsibility is concerned, each employee of the engineer cadre has to been given the stipulated time to get the work done with the assistance of the staff and report it to the higher officers. If any delay is there getting the work done, then proper explanation has to be submitted to the higher officers duly submitting the genuine reason for delay in rectifying the matter.

Today, the electricity is being considered the essential commodity and any trouble or breakdown in the system will not be tolerated by the Consumer as well as the industries, hospital and railway and it so far which the concerned officers have been held responsible for that. The main motive of these reforms is to serve the consumer in a better way with quality, reliability of power supply at a reasonable, affordable price. This is achieved by the process of reforms which facilitated the private enterprise entrance in to the power generation market and supplying power at a reasonable cost and providing service to the consumer in the metropolitan cities like Mumbai etc by BSES Ltd., As the days went by the Government of India and State Government could not develop the infrastructure development, as its main expenditure has been used up on agriculture law and order, medical services and primary and secondary education and of course in the form of subsided to some sectors of the state. With these priorities, the Government could not concentrate on the infrastructural facilities like power, roads and airports etc., but the development in the country could be achieved with these sectors, in view of the above, the Government of India had taken a bold initiative to unite the private partnership in some sectors, contemplating the future requirement of power for industrial growths.

\section{Organizational Change and its Effect on Employees}

It is already explained that the higher officers cadre strengths has been increased five times, while lower field level strength has not been increased that much. Close supervision on the work is increased putting more bonus on the employee. For instance, the revenue collection responsibility put the field officer change of the 16 
sale of energy, then $100 \%$ targets have to be achieved at the end of the each month against the demand, then the employee has to work responsibly and strive to fulfil his requirements.

\section{Not Exceeding the Allocated Quota of Energy}

Each sub-station on the $33 \mathrm{KV}$ level and section is given certain energy for month based on the availability. Within the stipulated amount of available energy; the section officer has to plan the distribution of power to all the feeders by limiting the energy. If the excess energy is drawn by the section officer, then he has to submit explanation for violating the rules. With these arrangements the indiscipline distribution of power from the grid can be regulated so that technical collapse of grid operations can be avoided.

\section{Implementation of Citizen Charters}

Government has strictly implemented citizen charters and instructed the employees in achieving the consumers the required services. If any failure of the supply in a particular locality is reported to the call centre over phone or by written complaint it should be attended within an hour by the department, otherwise penalty will be imposed on the concerned staff depending on the nature of the fault. This type of charter will hold the great responsibility and accountability on the part of the department employee in serving the consumer.

\section{Assessing the Performance of the Employees in Each Cadre}

Every month each engineer is assessed on his performance by the management on the basis of the giving nature of the works attended and based on his discharge of duties, he is awarded a certain grade and based on his grading he is commended upon with non-monitory benefit once in a year. If his performance is not up to the mark then he is deputed for training where his technical and management skills are developed to improve his performance. Human resource department and Government of India are encouraging this sort of training programmes and funding is also given to such institutions. With this the employees can update their 
skills and motivation they are also given developed to compete with other employees.

\section{Good Pay Scale Structures with the Profits}

With better consumer service, and the immediate attendance of the outages, the power can be supplied with minimum interruption time there by increasing the energy sales and the revenue. Load management can be done with Availability Based Tariff(ABT), where power can be drawn when the frequency is high and controlled drawn when frequency is low causes the organization to control the cost of sale of power there by directly controlling the cost of purchase. Such sort of activities will improve the organizations financial status. With this measures good financial status of the company which will in turn help the pay scale rises for the employees.

\section{Controlling the Internal Expenditure There By Controlling the Budgets}

With the better internal cost controls viz. controlling telephone bills of the employees, other allowance bills and purchasing of stationery items will cause the organization to improve the financial strength. With this the Government can improve medical facilities and personal loan schemes, and also the house building advances to the employees.

\section{Promotional Avenues for the Employees with Post-Reforms}

As far as promotional avenues of the employees with post reforms processes are concerned, they are decreased to the maximum extent. This is because, the number of sanctioned posts remains the same as in earlier, but the Government as well as corporation management is reluctant to recruit new engineers to the establishments in order to control their administrative expenditure. So, the works are carried out by the existing staff with assistance of the outsourcing personnel. Basically, this is based on the recommendations of the World Bank to promote the contract system. With this the higher level cadre promotion is affected adversely due to which the employees are frustrated with their monotonous duties. But with the existing scenario employees have 18 
to change their mind set as the change is inevitable in the organization with the new Government policies.

Opinion Survey Analysis of Employee of A.P.S.P.D.C.Ltd.On Organizational Change:

\begin{tabular}{|c|c|c|c|}
\hline & \multicolumn{3}{|c|}{ Number of Respondents } \\
\hline & Agree & $\begin{array}{l}\text { Neither } \\
\text { agree nor } \\
\text { disagree }\end{array}$ & Disagree \\
\hline $\begin{array}{l}\text { Do you think Change is Necessary in } \\
\text { your Organization? }\end{array}$ & $45(60 \%)$ & $30(40 \%)$ & -- \\
\hline $\begin{array}{l}\text { If Change is accepted by the employee } \\
\text { / should it be accordance with the past } \\
\text { system? }\end{array}$ & $45(60 \%)$ & $30(40 \%)$ & -- \\
\hline $\begin{array}{l}\text { Do you think change brought more } \\
\text { onus on you compared to before? }\end{array}$ & $60(80 \%)$ & $15(20 \%)$ & -- \\
\hline $\begin{array}{l}\text { With this change does the consumer } \\
\text { get benefited? }\end{array}$ & $53(70 \%)$ & $22(30 \%)$ & -- \\
\hline $\begin{array}{l}\text { Do you think, the existing administrate } \\
\text { set up will create conducive } \\
\text { environment for works? }\end{array}$ & $45(60 \%)$ & $30(40 \%)$ & -- \\
\hline $\begin{array}{l}\text { Do you think organizational goals can } \\
\text { be achieved with this? }\end{array}$ & $38(50 \%)$ & $37(50 \%)$ & -- \\
\hline $\begin{array}{l}\text { Do you accept that financial condition } \\
\text { of the organization improve with this } \\
\text { change? }\end{array}$ & $39(52 \%)$ & $36(48 \%)$ & -- \\
\hline $\begin{array}{l}\text { Do you accept that pay scale structure } \\
\text { is on par with your expectation after } \\
\text { the change? }\end{array}$ & $53(70 \%)$ & $22(30 \%)$ & -- \\
\hline $\begin{array}{l}\text { Do you think that employee morale } \\
\text { increased with change? }\end{array}$ & $38(50 \%)$ & $36(48 \%)$ & $3(2 \%)$ \\
\hline $\begin{array}{l}\text { Do you accept the sense of belonging } \\
\text { and commitment on part of the } \\
\text { employees? }\end{array}$ & $53(70 \%)$ & $22(30 \%)$ & -- \\
\hline
\end{tabular}




\begin{tabular}{|c|c|c|c|}
\hline $\begin{array}{l}\text { Do you accept that employees are } \\
\text { facilitated to find out their strength / } \\
\text { weaknesses from higher officers/ } \\
\text { colleagues after change? }\end{array}$ & $38(50 \%)$ & $37(50 \%)$ & -- \\
\hline $\begin{array}{l}\text { Do you think the Training of } \\
\text { Development Program conducted for } \\
\text { Performance Appraisal is a good idea? }\end{array}$ & $67(90 \%)$ & $08(10 \%)$ & -- \\
\hline $\begin{array}{l}\text { Do you think grievance handing by the } \\
\text { Organization is Fair and Transparent } \\
\text { after Change? }\end{array}$ & $38(50 \%)$ & $37(50 \%)$ & -- \\
\hline $\begin{array}{l}\text { Do you accept that the Promotional } \\
\text { Polices is based on Merit only and } \\
\text { Unbiased? }\end{array}$ & $08(10 \%)$ & -- & $67(90 \%)$ \\
\hline $\begin{array}{l}\text { Do you agree that employers have a } \\
\text { good feeling about our Organization? }\end{array}$ & $22(30 \%)$ & $53(70 \%)$ & -- \\
\hline $\begin{array}{l}\text { Performance of the employee } \\
\begin{array}{l}\text { is } \\
\text { oriented towards } \\
\text { Production? }\end{array}\end{array}$ & $18(24 \%)$ & $57(76 \%)$ & -- \\
\hline $\begin{array}{l}\text { Do you agree that Co-operative Work } \\
\text { is in togetherness and Sharing of } \\
\text { information Exists in Practice? }\end{array}$ & $20(26 \%)$ & $55(74 \%)$ & -- \\
\hline $\begin{array}{l}\text { Do you accept the Spirit is of high } \\
\text { order in AP Transco? }\end{array}$ & $15(20 \%)$ & $60(80 \%)$ & -- \\
\hline $\begin{array}{l}\text { Do you think weaknesses of employees } \\
\text { are Communicated in a non - } \\
\text { threatening Manner? }\end{array}$ & $71(94 \%)$ & $04(6 \%)$ & -- \\
\hline $\begin{array}{l}\text { Do you accept that the promotional } \\
\text { avenues are improved by creating } \\
\text { super innumeracy posts to avoid } \\
\text { frustration among employees? }\end{array}$ & $75(100 \%)$ & -- & --- \\
\hline
\end{tabular}

\section{Findings}

- Sixty percent of the sample responded stating that change is necessary in the organization, so as to compete in the present competitive environment. 
- Sixty percent of the sample respondents opined that if the change is inevitable, it should not violate or differ completely from the old system and should be in accordance with the past system in the case of service matters and other leave rules and regulations.

- Eighty percent of the employees stated that more responsibility is fixed compared to earlier in all aspects. With this, the employees will work with dedication thereby improving the overall efficiency.

- Seventy percent of the employees stated that the consumer gets benefited with the change of organization as the employee feels responsible in serving the consumer.

- Fifty percent of the employees stated that the organizational goals can be achieved in a better way with this change as every employee has felt that the work was work ship.

- Fifty two percent of the employees stated that financial condition of the organization has been improved with the better economic policies and better revenue collection methods.

- Seventy percent of the employees stated that the pay scale structure is satisfactory after the change as the financial status of the organization has increased with the above said methods. With this, the employee works with more motivation, for he/she is satisfied with the pay scale. This enhances the employee morale and the work allocation in a better way.

- Fifty percent of the employees stated that grievance handling by the organization is fair and transparent and the citizen charters implemented by the organization will help the consumer to get the better services.

- Cent percent employees stated that the supernumerary posts are to be created to motivate the employees in order to avoid frustration among them for not having promotions for years together. So, a numbers of extra posts are to be created for promoting the staff according to merit or this will improve the morale of the employee. 
- Ninety percent of the employees state that training and development is necessary for every employee to update the skills to meet the future challenges in the case of the power sector and an equal per cent of respondents stated that promotional policies have to be re-structured and the organization has to set up a mechanism in order to give a helping hand to the meritorious employees.

\section{Conclusion}

Change in organizations is inevitable towards productivity, efficiency and effectiveness. If change is accepted, it should be in accordance with the pre system, in respect of service matters, conduct rules, and leave rules, and other benefits.

The employees will work to their full capacity but not by jeopardizing their benefits. As for as the work responsibility is concerned, it has certainly increased with the changed organization structure. The employee accountability is for also increased, this in turn has improved the service availability to the consumers compared to before.

Majority of the employees opine that training is more important to update the skills and thereby improving the work. The quality management has already adapted this practice by deputing every employee for 15 day training and corporate training is given to them in the institute located at Hyderabad. Finally majority of the employees stated that the change will certainly improve the efficiency of the organization to deliver better consumer services.

After the reforms employees got affected by stagnation in the cadre. So, a numbers of super numeric posts have to be created in order to satisfy the employees and work can be extended to full extent by satisfying the need of the employees.

\section{References}

Andrews, J., Cameron, H., \& Harris, C. (2008). All change? Managers experience of organizational change in theory and practice. Journal of Organizational Change Management, 21(3), 300-314. 
Bennis, W. G. (1989). On becoming a leader. Reading, Mass: AddisonWesley, 23.

Branford D. R., \& Forrester P. (2003).Managing planned and emigrant change, an operations management environment international. Journal of POM23(J) 546-564.

Brown, S., \& Eisenhardt, K. (1998). Competing on the Edge. Harvard University Press.

Burnes, B. (2004). Managing change: A strategic approach to organisational dynamics, 4th ed. Harlow: Prentice Hall.

Cao, G. \& Mchugh, M. (2005). A systematic view of change management and its conceptual underpinning. Systemic Practice and Action Research,18(5) 475-490.

Chakravarthy. B. S. (1986). Measuring strategic performance. Strategic Management Journal.7(5).437-58.

Davis, K., \& Pareek, U. (1988). Implementing change and managing organizational change, Oxford \& IBM Publishing.

Doyle, M., Claydon, T. \& Buchanen. D. (2000). Mixed results, lousy process the management experience of organizational change. British Journal of Management, 11, S59-S80.

Eldrood II, P. D. \& Tippett, D. D. (2002). The death valley of change. Journal of Organization Change Management, 15(3), 273-291.

Graetz, F. (2000). Strategic change leadership. Emerald Management Reviews. 38(8) 550-562.

Hersconitch, L., \& Meyer J. P. (2002).Commitments to organization change extension of a three component model. Journal of Applied Psychology, 87( 3). 474-87.

Luecke, K. (2003). Managing Change and Transition. Harvard: Harvard University Press.

Luecke, R. (2003). Managing change and transits. Boston MA: Harvard Business School press.

Moran, J. W., \& Brightman, B. K. (2001). Leading organizational change. Career Development International. 6(2), 111-118.

Paton, R., \& McCalman, J. (2000). Change management: A guide to effective implementation (2nd Ed.). London: Paul Chapman Publishing. 
Rieley J. B. \& Clarkson, I. (2001). The impact of change in performance. Journal of Change Management, 2(2) 160-172.

S. P. Robbins (2000). Change Mgt: HRD Implementation. 